\title{
REVIEWS.
}

\section{TEXT-BOOK OF MEDICINE.} (Fourth Edition.)

Edited by Dr. J. J. Conybeare. E. \& S. - Livingstone. Edinburgh. 1939. Price 21s. 0d.

The third edition of the book appeared as recently as 1936 and a reprint was necessary last year. That this (the fourth) edition has been called for so soon afterwards is evidence of the place that the text-book occupies in medical literature and that the editor and his co-authors are determined that the book should be as up-todate as possible, and worthy of this position, is revealed by the changes in the text which they have taken the opportunity of introducing. In the present edition, for example, there appears for the first time a section on psychological medicine which should go some way to meet the demand that the medical student must have an introduction to this important subject. Otherwise the various sections remain as before but with some notable additions, such as the use of protomine insulin in the treatment of diabetes mellitus a description of the recently described specific venereal disease called lymphogranuloma inguinale and also of neuromyelitis optica, disseminated encephalitis and hypertensive encephalopathy.

We are sure that the terse concise descriptions of the various diseased processes and discussions of their etiology, with an absence of all padding, the handy size of the volume, the clear type, and an unusually detailed index will cause this volume to remain one of the chief favourites of the medical student.

\section{THE BRITISH}

\section{ENCYCLOPADIA OF MEDICAL PRACTICE, Vol. II. SCARLET FEVER TO TESTIS UNDESCENDED.}

Edited by Sir Humphry Rolleston, Bt. Butterworths Medical Publications. London. 1939. Price 35s. 0d.

This volume of the Encyclopædia, which maintains the high standard set by its predecessors, is particularly valuable as it contains up-to-date, detailed and yet concise treatises of some most important subjects. Among those specially calling for mention are "Syphilis," by Col. L. W. Harrison; "Diseases and Deformities of the Spine," by Sir John Fraser; "Diseases of the Spinal Cord," by Drs. Walshe and Elkington, and Mr. Harry Jackson; "Spine," by Dr. Hamilton Fairley; "Statistics," by Major Greenwood; "Tumours of the Skin," by Dr. Sydney Thomson; "Sterility," by Dr. Eardley Holland and Mr. Kenneth Walker; "Sterilization," by Drs. Tredgold and Beattie, and Mr. Kenneth Walker; "Septicæmia and Bacteriæmia," by Prof. John A. Ryle and Dr. S. D. Elliott; " Occupational Diseases," by Drs.
Henry and Horner, and one on "Sex Hormones," by Prof. E. C. Dodds, and Drs. Bishop and Foss. The various articles in this particular volume are specially well illustrated by photographs of clinical pictures, radiographs and histological preparations. The fact that there are six coloured plates shows that no expense has been spared in the production of a work which is a credit to the various authors, to the editor and to the publishers.

\section{TREATMENT BY MANIPULA- TION IN GENERAL AND CONSULTING PRACTICE.}

3rd Edition by A. G Timbrell Fisher, M.B., F.R.C.S. pp. 255. H. K. Lewis \& Co. London. 1939. Price 12s. 6d.

This book is the third edition of this well known work and has been brought up to date and partially re-written.

Time was when the neglect of manipulative treatment was regarded as one of the "reproaches" of the medical profession, but the same can hardly be said to-day, and occasion ally, one wonders whether the pendulum has overswung and whether the old adage "fools rush in where angels fear to tread" may not have an application to its use to-day.

So that a fresh edition of this book iș welcomed, for it bristles with sound knowledge and explicit instruction. In spite of this, it cannot be over emphasised that continual observation and practice is the only real safeguard, and that merely reading a book, however good, will never justify the practice of this most difficult branch of medicine.

\section{MODERN ANESTHETIC PRACTICE.}

\section{No. III Practitioner Handbooks.}

Edited by SIR HUMPHRY Rolleston and Dr. Alan A. Moncrieff. Eyre and Spottiswoode. 1938. Price 10s. 6d.

This book begins with a well balanced and thoughtful introduction by Dr. Blomfield, comparing new methods with old. His conclusion $\frac{7}{2}$ that anaesthetics are falling more and more into the hands of specialists might well be made a $\mathrm{N}$ plea for more post graduate instruction of general practitioners to provide local specialists in areas outside the great cities.

Dr. Hewer's masterly summing up of the relative toxicities of the various drugs is most encouraging, and should go far to keep the drugs used in safer channels than before, and all the $\bar{D}$ theoretical aspects of the subject are well handled with knowledge and with an eye to the practical. 